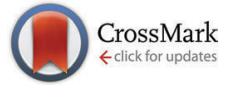

Cite this: J. Mater. Chem. B, 2015, 3, 3777

Received 4th February 2015, Accepted 2nd April 2015

DOI: $10.1039 / c 5 t b 00253 b$

www.rsc.org/MaterialsB

\title{
Peptide-directed crystal growth modification in the formation of $\mathrm{ZnO} \uparrow$
}

\author{
Anna Sola-Rabada, ${ }^{a}$ Mei-Keat Liang, ${ }^{a}$ Martin J. Roe ${ }^{b}$ and Carole C. Perry ${ }^{{ }^{a}}$
}

\begin{abstract}
Biomolecule-mediated synthesis is fascinating in terms of the level of control and the intricate hierarchical structures of the materials that can be produced. In this study we compare the behavior of a phage display identified peptide, EAHVMHKVAPRP (EM-12) with that of a mutant peptide EAHVCHKVAPRP (EC-12), having additional complexation capability, on the formation of $\mathrm{ZnO}$ from solution. The synthesis conditions $\left(\mathrm{Zn}\left(\mathrm{CH}_{3} \mathrm{COO}\right)_{2}-\mathrm{NH}_{3}\right.$ hydrothermal method at $\left.50{ }^{\circ} \mathrm{C}\right)$ were chosen to generate rod-shaped $\mathrm{ZnO}$ via layered basic zinc salts (LBZs) as intermediates. Both peptides affected the crystal formation process by moderating the amount of $\mathrm{Zn}^{2+}$ ions in solution (EC12 having a greater effect than EM12) but only EC12 was shown to interact with the solid phase(s) formed during the reaction. Depending on the peptide concentration used, EM-12 was shown to delay and/or suppress $\mathrm{ZnO}$ formation. In contrast, additions of EC-12, although leading to the retention of higher levels of $\mathrm{Zn}^{2+}$ ions in solution did not similarly delay the transformation of the intermediate phases to $\mathrm{ZnO}$ but were found to dramatically modify the morphology of $\mathrm{ZnO}$ crystallites with mushroom shaped crystals being formed. From the results of detailed materials characterization and changes in the morphology observed, the interactions between the peptide(s) and solution and solid state species present during the process of $\mathrm{ZnO}$ crystal formation in the presence of EM-12 and EC-12 are proposed.
\end{abstract}

\section{Introduction}

The identification of biomineral-associated biomolecules has shed light on how biominerals are formed in living organisms. This has also led to the use of the bioinspired/biomimetic approach for materials synthesis, ${ }^{1-4}$ even for non-biologically produced minerals such as $\mathrm{ZnO}{ }^{5}$ Despite $\mathrm{ZnO}$ not being found in living organisms, to date, more than twenty ZnO-binding peptides (ZnO-BPs) have been identified from either cell surface display ${ }^{6,7}$ or phage display libraries. ${ }^{8-11}$ However, only a few peptides such as GLHVMHKVAPPR (G-12), ${ }^{12,13}$ EAHVMHKVAPRP $(\mathrm{EM}-12)^{9,14}$

\footnotetext{
${ }^{a}$ Biomolecular and Materials Interface Research Group, Interdisciplinary Biomedical Research Centre, School of Science and Technology, Nottingham Trent University, Clifton Lane, Nottingham, NG11 8NS, UK. E-mail: Carole.Perry@ntu.ac.uk

${ }^{b}$ Advanced Materials Research Group, X-ray Photoelectron Spectroscopy, Faculty of Engineering, The University of Nottingham, University Park, Nottingham, NG7 2RD, UK

$\dagger$ Electronic supplementary information (ESI) available: XPS analysis for the study of the ubiquitous carbonaceous contamination, and XPS data including the relative ratio of $\mathrm{Zn} / \mathrm{O}$ and $\mathrm{BE}(\mathrm{eV})$ for $\mathrm{O} 1 \mathrm{~s}, \mathrm{C} 1 \mathrm{~s}$ and $\mathrm{Zn} 2 \mathrm{p}_{3 / 2}$ for samples analyzed; calibration curves used for peptide quantification in solution; calculated $\mathrm{p} K_{\mathrm{a}}$ of peptide side chains using Marvin calculator; $\mathrm{Zn}^{2+}$ in solution for EC12-added reactions; XRD and TGA results for 24 hour-precipitates produced in the presence of EC-12; dimension analysis of ZnO crystals obtained from EM-12added reactions (48 hours); lattice strain modification for ZnO planes in the presence of EC-12; and mass spectra for peptides. See DOI: 10.1039/c5tb00253b
}

and derivatives GLHVMHKVAPPR-GGGC $(\mathrm{GT}-16)^{12,15}$ and EAHVMHKVAPRP-GGGSC (ET-17) ${ }^{9,15}$ have been studied further. The addition of GT-16 during ZnO synthesis has been shown to reduce the aspect ratio of the $\mathrm{ZnO}$ crystals formed. ${ }^{8}$ In order to unravel the cause(s) of aspect ratio reduction by this $\mathrm{ZnO}-\mathrm{BP}$, our group conducted some studies using G-12 ${ }^{12,13}$ and/or GT-16. ${ }^{12}$ The direct evidence obtained suggested that (i) $\mathrm{ZnO}$ aspect ratio reduction occurs via an adsorption-growth inhibition mechanism, (ii) G-12 adsorbing on both (0001) and (1010) planes of $\mathrm{ZnO}$ is sufficient to reduce $\mathrm{ZnO}$ aspect ratio (GGGC-tag is not essential); and, (iii) that the GGGC-tag is responsible for the selective adsorption of GT-16 on the (0001) plane of ZnO crystals. Also, the addition of G-12 in different $\mathrm{ZnO}$ experimental systems led to a modification of the growth mechanisms. ${ }^{13}$ Studies by others have shown that the addition of ET-17 into stable $\mathrm{Zn}(\mathrm{OH})_{2}$ sols catalyzes $\mathrm{ZnO}$ formation, directing a flower-type anisotropic crystal growth. ${ }^{9}$ The catalytic effect of ET-17 is generated either by the presence of the EM-12 segment or GGGSC-tag. ${ }^{9}$ The catalytic effect of ET-17 was further confirmed as ET-17 attached to a genetically modified-collagen template was able to generate $\mathrm{ZnO}$ nanowires. ${ }^{16} \mathrm{~A}$ study proposed to understand the interactions taking place between the $\mathrm{ZnO}$ surface and EM-12 showed that conformational changes as well as charged amino acids and residues adjacent to the charged aminoacids are critical to the binding to $\mathrm{ZnO} .{ }^{17}$ It was concluded that the electrostatic interaction between $\mathrm{ZnO}$ particles and 
ZnO-BPs was enthalpy-driven, and involved hydrogen bonding, as also suggested by Patwardhan et $a .^{18}$ The specific binding sites of the EM-12 peptide have been explored, ${ }^{19}$ with the shorter sequences; HVMHKV and HKVAPR having either high specificity and/or affinity for ZnO nanoparticles. Additionally, it was proposed that $\mathrm{ZnO}$ binding did not depend on hydrophobicity or other physical parameters but ZnO recognition of the specific amino acid alignment of these peptides. ${ }^{19}$ Morphology changes observed for $\mathrm{ZnO}$ growth in the presence of ZnO-BPs did not lead to random morphologies. For example, the addition of EM-12 or dipeptides from its sequence (i.e. Met-His or His-Lys) during solution synthesis using $\mathrm{Zn}(\mathrm{OH})_{2}$ as a precursor, suppressed crystal growth of $\mathrm{ZnO}$ in the (0001) direction. ${ }^{14}$

The coordination of $\mathrm{Zn}^{2+}$ with proteins plays an important role for the structural stability and functionality of proteins in living organisms as evidenced in metalloproteins such as metallothionine and zinc fingers of DNA-binding proteins. ${ }^{20} \mathrm{Zn}^{2+}$-protein complexation occurs at specific domain(s) via the side chains of amino acid residues namely; sulphur atoms of cysteine and methionine, nitrogen atoms of histidine, and oxygen atoms of aspartic acid and glutamic acid. ${ }^{20}$ In experimental studies using a $\mathrm{Zn}\left(\mathrm{NO}_{3}\right)_{2}-$ HMTA hydrothermal reaction, Gerstel et al. demonstrated that the presence of aspartic acid, glutamic acid, and their corresponding dipeptides produced layered basic zinc salts (LBZs) as opposed to the expected $\mathrm{ZnO}^{21}$ They also observed the formation of soluble complexes when higher concentrations of these additives were used and proposed that $\mathrm{Zn}^{2+}$-additive complexation via electrostatic interaction was responsible for LBZs or soluble complex formation. ${ }^{21}$ More recently, it has been shown that the presence of peptides with different isoelectric points (in the acid, basic and neutral range) using a $\mathrm{Zn}\left(\mathrm{NO}_{3}\right)_{2}-\mathrm{NaOH}$ hydrothermal reaction also formed LBZs as a metastable phase during the precipitation process. It was suggested that negatively charged peptides intercalated easily in metastable LBZs. ${ }^{22}$

Previous studies have shown that the formation of $\mathrm{ZnO}$ (without additives) occurs via intermediate(s), LBZs, that only later transform to the oxide phase $(\mathrm{ZnO}) .{ }^{23-29}$ This crystallization process usually occurs by a phenomenon known as Ostwald's Law of phases $^{30}$ in which a metastable phase is formed prior to the formation of the stable phase. In a recent study conducted by our group, the $\mathrm{ZnO}$ growth mechanism without the presence of additives has been described and compared for two different hydrothermal methods: (a) zinc acetate $\left(\mathrm{Zn}\left(\mathrm{CH}_{3} \mathrm{COO}\right)_{2}\right)$ and ammonia $\left(\mathrm{NH}_{3}\right)$ and (b) zinc nitrate hexahydrate $\left(\mathrm{Zn}\left(\mathrm{NO}_{3}\right)_{2}\right.$. $6 \mathrm{H}_{2} \mathrm{O}$ ) and 1,3-hexamethylenetetramine (HMTA). ${ }^{31}$ Both synthesis routes supported the growth of twinned hexagonal rods. However, the progression of solid phase transformation from LBZs to ZnO showed a dissolution/reprecipitation process in the $\mathrm{Zn}\left(\mathrm{CH}_{3} \mathrm{COO}\right)_{2}-\mathrm{NH}_{3}$ system, which did not occur for $\mathrm{Zn}\left(\mathrm{NO}_{3}\right)_{2} \cdot 6 \mathrm{H}_{2} \mathrm{O}-\mathrm{HMTA}$ system. ${ }^{31}$

In the current study, the effect of the peptides EM-12 (identified by phage display) and EC-12 $\ddagger$ during $\mathrm{ZnO}$ formation was investigated using a $\mathrm{Zn}\left(\mathrm{CH}_{3} \mathrm{COO}\right)_{2}-\mathrm{NH}_{3}$ hydrothermal method. ${ }^{32}$

\$ EM-12, 12-mer peptide containing methionine; EC-12, 12-mer peptide containing cysteine.
A specific aim of the investigation was to explore the effect of increasing number of potential complexing groups on $\mathrm{ZnO}$ formation, for instance, the replacement of methionine $\left(\mathrm{M}_{5}\right)$ with cysteine $\left(\mathrm{C}_{5}\right)$ in the peptide sequence.

\section{Results and discussion}

\section{Delay/suppression of ZnO Formation by EM-12}

The role of EM-12 in affecting ZnO formation was explored by characterization of the precipitates and analysis of components present in solution at a series of reaction times. Previous studies have shown that the formation of $\mathrm{ZnO}$ occurs via intermediate(s), layered structures that only later transform to the oxide phase $(\mathrm{ZnO}){ }^{23-29}$ In this system $\left(\mathrm{ZnAc}_{2}-\mathrm{NH}_{3}\right)$, the intermediate compounds have been identified as Layered Basic Zinc Acetate (LBZA) $)^{23-29}$ and Layered Basic Zinc Acetate Carbonate (LBZAC) ${ }^{27,28,31}$ with formulae, $\mathrm{Zn}_{5}(\mathrm{OH})_{8}\left(\mathrm{CH}_{3} \mathrm{COO}\right)_{2} \cdot 2 \mathrm{H}_{2} \mathrm{O}$ and $\mathrm{Zn}_{5}(\mathrm{OH})_{x}\left(\mathrm{CH}_{3} \mathrm{COO}\right)_{y}\left(\mathrm{CO}_{3}\right)_{z} \cdot n \mathrm{H}_{2} \mathrm{O}(x+y+z=10)$, respectively. Based on the characterization of the 24 hour precipitates using XRD and SEM (Fig. 1), the addition of $0.1 \mathrm{mM}$ of EM-12 (Zn-topeptide ratio $=150: 1$ ) did not affect $\mathrm{ZnO}$ formation significantly. This was inferred from the observation of hexagonal rods (Fig. 1a(i)) and the detection of characteristic diffraction peaks of $\mathrm{ZnO}$ (Fig. 1a(i)) at $31.98^{\circ}, 34.63^{\circ}$, and $36.48^{\circ}$ assigned

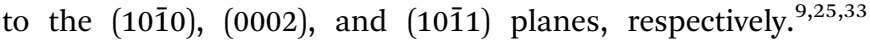
However, in the presence of EM-12 at higher concentrations, either a delay or suppression of $\mathrm{ZnO}$ formation was observed. In the presence of $0.2 \mathrm{mM}$ EM-12 and above (Fig. 1a(iii)-(vi)), a layered structure with irregular shapes was observed, with the main diffraction peak at $6.86 \pm 0.03^{\circ}$, attributed to the (001) plane of LBZA $^{32-34}$ with an interlayer spacing of $12.94 \pm 0.05 \AA$. This is in agreement with previously reported interlayer spacing values of $\sim 12-15 \AA$ for LBZA. ${ }^{25,29,35,36}$ The presence of LBZAC was discounted as $00 l$ reflections would have had a larger interlayer spacing $(\sim 19 \AA)$ produced by the co-intercalation of both acetates and carbonate ions. ${ }^{27,28}$ For samples with $0.2 \mathrm{mM}$ and $0.3 \mathrm{mM}$ of peptide, the detection of $\mathrm{ZnO}$ as the major component was delayed to 48 hours (Fig. 1b(iii)-(iv)). This effect will be referred to as "delayed-formation" hereafter. In the presence of $0.4 \mathrm{mM}$ EM-12, both LBZA and ZnO were detected in the sample at 48 hours (Fig. $1 \mathrm{~b}(\mathrm{v})$ ) and for the highest EM-12 concentration studied; $0.5 \mathrm{mM}$, LBZA remained the major phase at 48 hours (Fig. 1b(vi)) suggesting the suppression of $\mathrm{ZnO}$ formation. The change in the twinning behavior of $\mathrm{ZnO}$ crystals (SEM images, Fig. 1b) with increasing EM-12 concentration was also observed, and will be discussed later in this article.

The delayed-formation of $\mathrm{ZnO}$ was also supported by subjecting the precipitates to thermal decomposition (TGA) which resulted in three stages of weight loss (Fig. 2a); first, the release of physisorbed water at temperatures below $100{ }^{\circ} \mathrm{C}$. $^{25,29}$ Second, the dehydration of intercalated water $\left(100{ }^{\circ} \mathrm{C}-168{ }^{\circ} \mathrm{C}\right)$ and/or the dehydroxylation of zinc hydroxide layers in LBZA $\left(168{ }^{\circ} \mathrm{C}-250{ }^{\circ} \mathrm{C}\right)$. Finally, the decomposition of acetate groups at temperatures from 250 to $400{ }^{\circ}$ C. $^{25,29}$ Total weight loss values of $31-38 \%$ have been reported for LBZA in the literature. ${ }^{26,29,31,37}$ In this study, 



Fig. 1 XRD diffractograms of precipitates collected in the presence of different concentrations of EM-12 at (a) 24 hours and (b) 48 hours. The diffraction peak arising from the aluminum sample holder is marked with an asterisk (*). $d$ denotes the interlayer spacing of LBZA formed. The corresponding SEM images of the precipitates are shown. All scale bars shown are $5 \mu \mathrm{m}$ and (i) to (vi) correspond to Blank, $0.1 \mathrm{mM}, 0.2 \mathrm{mM}$, $0.3 \mathrm{mM}, 0.4 \mathrm{mM}$ and $0.5 \mathrm{mM}$ of $\mathrm{EM}-12$, respectively.
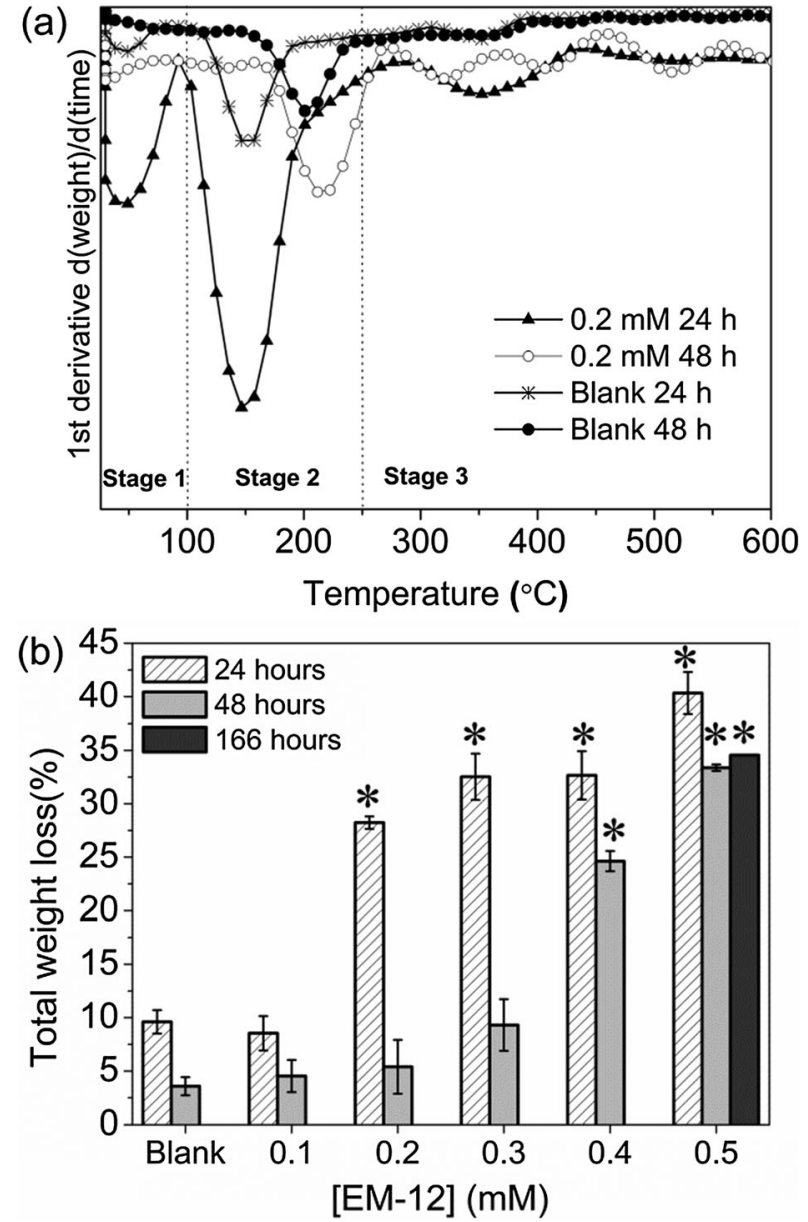

Fig. 2 (a) Representative TGA 1st derivative weight loss curves of precipitates collected at 24 and 48 hours with [EM-12] of $0 \mathrm{mM}$ (Blank) and $0.2 \mathrm{mM}$; and (b) total weight loss (\%) of precipitates collected in the presence of different concentrations of EM-12 $(0.1-0.5 \mathrm{mM})$ at 24 hours, 48 hours and 168 hours ( $0.5 \mathrm{mM}$ EM-12 only). The starred bars correspond to samples that are mainly LBZA as observed by XRD.

the weight losses observed in the presence of $0.2 \mathrm{mM}$ EM-12 and above, supported the presence of LBZA in the samples (Fig. 2b). The reduction in weight loss from 24 to 48 hours was due to the phase transformation from LBZA to ZnO. For the highest concentration of peptide studied; $0.5 \mathrm{mM}$, LBZA remained the major phase up to 168 hours ( $\sim 34 \%$ ) (Fig. $2 b$ ). Hence, the addition of $0.5 \mathrm{mM}$ suppressed $\mathrm{ZnO}$ formation to the extent that LBZA remained stable up to 168 hours while lower EM-12 concentrations only slowed down the rate of conversion of LBZA to ZnO (Fig. 2b).

Further evidence for the various phases came from XPS analysis of precipitated material. The survey spectra showed the presence of $\mathrm{Zn}, \mathrm{O}$ and $\mathrm{C}$ in all the precipitates studied (Blanks, $0.2 \mathrm{mM}$ and $0.4 \mathrm{mM}$ of EM-12), with peaks in the $\mathrm{Zn} 2 \mathrm{p}_{3 / 2}$, O 1s and C 1s regions; having BE values of $1021.7 \pm$ $0.2 \mathrm{eV}, 531.6 \pm 0.1 \mathrm{eV}, 285.0 \pm 0.0 \mathrm{eV}$, respectively; (Fig. 3). From the plot of $\%$ area of the $\mathrm{C} 1 \mathrm{~s}$ and $\mathrm{Zn} 2 \mathrm{p}_{3 / 2}$ peaks at different concentrations of peptide, an increase of the $\mathrm{C} 1 \mathrm{~s}$ region with peptide addition can be observed (Fig. 3) supporting the 

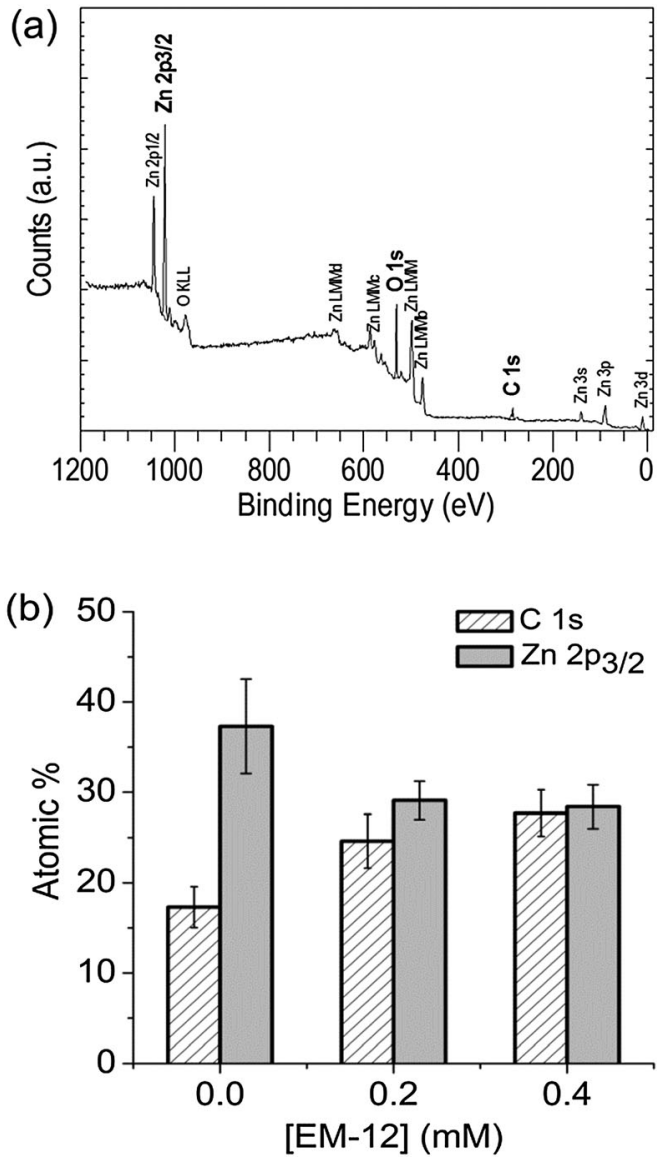

Fig. 3 (a) XPS survey spectrum recorded from an as-deposited precipitate collected at 24 hours with [EM-12] of $0.4 \mathrm{mM}$ and (b) atomic \% of carbon and zinc for the 48 hour precipitate with $0.0 \mathrm{mM}$ (Blank), $0.2 \mathrm{mM}$ and $0.4 \mathrm{mM}$ of $\mathrm{EM}-12$

supposition that the presence of EM-12 slowed down the rate of conversion of LBZA to $\mathrm{ZnO}$, as more $\mathrm{C}$ is expected with the presence of the intermediate. Even though the data obtained include traces of "adventitious carbon", usually present in the XPS experiment (ESI $1 \dagger$ ), the remaining carbon was thought to be from LBZA, as identified by XRD and TGA and further evidenced by the analysis of core-level spectra for $\mathrm{Zn} 2 \mathrm{p}_{3 / 2}$, C $1 \mathrm{~s}$ and $\mathrm{O} 1 \mathrm{~s}$ regions, Fig. 4. The presence of $\mathrm{Zn}$ metal was discarded in our system as the Zn LMM peak was shown to be at $988.4 \mathrm{eV}$ attributable to $\mathrm{ZnO},{ }^{38}$ whereas the kinetic energy peak for metallic $\mathrm{Zn}$ would be expected at $992 \mathrm{eV}{ }^{38}$ The different local
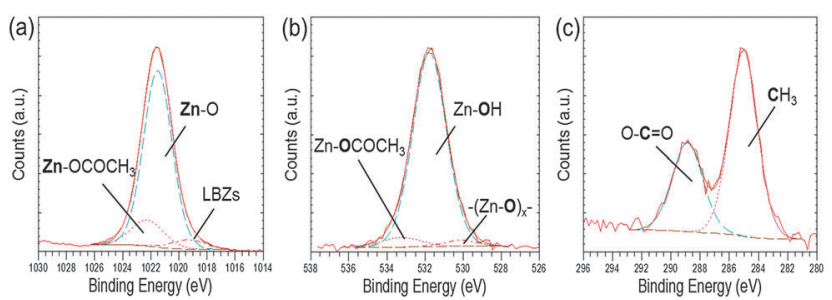

Fig. 4 High resolution core level spectra of an as-deposited precipitate collected at 24 hours with [EM-12] of $0.2 \mathrm{mM}$ for (a) $\mathrm{Zn} 2 \mathrm{p}_{3 / 2}$, (b) $\mathrm{O}$ 1s and (c) C 1s.

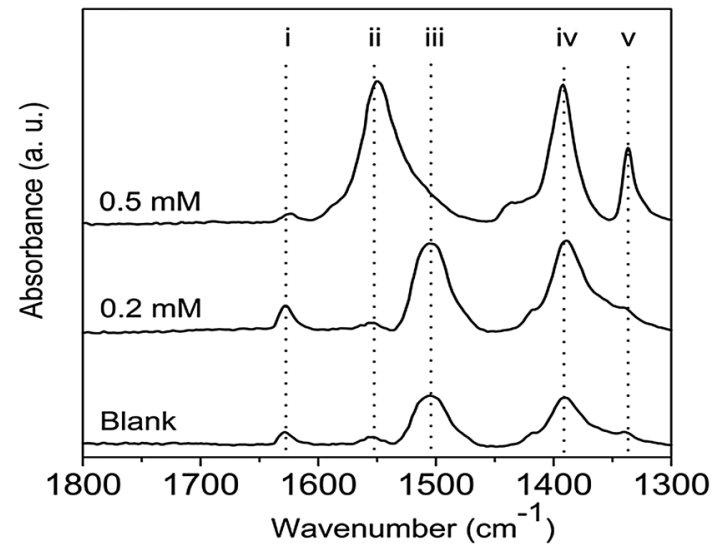

Fig. 5 FTIR of 48 hour precipitates collected at different concentrations of EM-12. The identification of the peaks (i) through to (v) is given in Table 1.

chemical states of each element in the precipitates indicated the presence of such element in a mixed environment, as is the case for LBZA with formula $\mathrm{Zn}_{5}(\mathrm{OH})_{8}\left(\mathrm{CH}_{3} \mathrm{COO}\right)_{2} \cdot 2 \mathrm{H}_{2} \mathrm{O}$. The peak position values, the full width half maximum (FWHM) and its identification are given in ESI $2 . t$

$\mathrm{ZnO}$ formation in the $\mathrm{ZnAc}_{2}-\mathrm{NH}_{3}$ system goes through several intermediates: LBZA and LBZAC. ${ }^{23-29,31}$ It is believed that the acetate groups in LBZA are gradually replaced by carbonate groups originating from dissolved $\mathrm{CO}_{2}$ present in solution, hence a new intermediate can be observed, LBZAC. At the later stages of $\mathrm{ZnO}$ formation (i.e. 48 hours) carbonate species can be dominant over acetate species, albeit in traces amounts relative to the amount of ZnO present. ${ }^{31}$ Although XRD data did not show the presence of these intermediates, traces of carbonates and acetates were detected by FTIR, Fig. 5 . For the sample prepared in the presence of $0.2 \mathrm{mM}$ EM-12, the peaks identified were similar to those for the Blank, and arose from traces of carbonate species present in the sample even though $\mathrm{ZnO}$ was the dominant compound detected by XRD. For the highest concentration of peptide studied, $0.5 \mathrm{mM}$, characteristic acetate peaks were detected (Table 1), confirming the delayed-formation of ZnO. This effect (delay-formation) can be due to either EM-12 stabilized LBZA or retained $\mathrm{Zn}^{2+}$ ions in solution; in both cases LBZA is favored and is discussed in more detail later in this paper.

\section{$\mathrm{Zn}^{2+}-\mathrm{EM}-12$ complexation and delayed/ suppression of $\mathrm{ZnO}$} formation

The presence of EM-12 extended the period where LBZA was stable as the intermediate phase, delaying or suppressing the formation of ZnO. According to Gerstel et al. ${ }^{21}$ amino acids having side chain functionality that interact electrostatically with $\mathrm{Zn}^{2+}$ in solution or on a crystal seed interface, would impose a strong influence on the morphology or the type of precipitate formed. ${ }^{21}$ Since amino acids capable of complexing with $\mathrm{Zn}^{2+}$, such as glutamic acid, histidine and methionine, are present in EM-12, they may reduce the amount of free $\mathrm{Zn}^{2+}$ in solution available for $\mathrm{ZnO}$ formation. Thus, the delay/ suppression of $\mathrm{ZnO}$ formation was hypothesised to be linked with changes in the amount of $\mathrm{Zn}^{2+}$ in solution when EM-12 
Table 1 FTIR absorption peaks identified in precipitates collected at different reaction times

\begin{tabular}{lll}
\hline Peak & Wavenumber $\left(\mathrm{cm}^{-1}\right)$ & Assignment \\
\hline $\mathrm{i}$ & $\sim 1620$ & O-H vibrational mode of the hydroxide slab in $\mathrm{LBZA}^{24,25}$ and/or O-H bending mode of water. \\
ii & $\sim 1550$ & Antisymmetric stretching \\
ii & $\left.\sim \nu_{\text {as }}\right)$ of $\mathrm{CO}_{2}{ }^{-25,27,40}$ \\
iii & $\sim 1505$ & Antisymmetric stretching $\left(\nu_{\mathrm{as}}\right)$ of $\mathrm{CO}_{3}{ }^{2-27,39}$ \\
iv & $\sim 1390$ & Symmetric stretching $\left(\nu_{\mathrm{s}}\right)$ of $\mathrm{CO}_{2}{ }^{-25,27,40}$ and/or $\nu_{3}$ of $^{27} \mathrm{CO}_{3}{ }^{2-27,39}$ \\
$\mathrm{v}$ & $\sim 1340$ & In-plane bending $\left(\delta_{\mathrm{s}}\right)$ or deformation of $\mathrm{CH}_{3}{ }^{27}$ \\
${ }^{a}$ The carbonate group has two $\nu_{3}$ modes assigned to the $\nu_{\text {as }}$ of $\mathrm{CO}_{3}{ }^{2-}$ band. $^{27}$
\end{tabular}

was present. This was confirmed from measurement of the $\mathrm{Zn}^{2+}$ concentration in the supernatants using ICP-OES. As previously mentioned, in this particular system $\left(\mathrm{ZnAc}_{2}-\mathrm{NH}_{3}\right)$ the progression of solid phase transformation from LBZs to $\mathrm{ZnO}$ goes through a dissolution/reprecipitation process in which precipitation of LBZA occurs immediately after mixing of reagents. ${ }^{31}$ The dissolution process takes place within 16 hours of reaction when $\mathrm{Zn}^{2+}$ are released back into solution, hence showing an increase of $\mathrm{Zn}^{2+}$ over time, followed by stabilization of $\mathrm{Zn}^{2+}$ in solution after 24 hours of reaction. ${ }^{31}$ As shown in Fig. 6a, this phenomenon is also observed in the presence of EM-12.

The addition of EM-12 increased the \% of $\mathrm{Zn}^{2+}\left({ }^{\%} \mathrm{Zn}^{2+}\right)$ in solution throughout the reaction (Fig. 6a and b). For data analysis, $t=1$ hour was used to represent the stage where LBZA was the major phase and $t=96$ hours to represent equilibrium. The increase of ${ }^{\%} \mathrm{Zn}^{2+}$ with respect to the Blank for these two
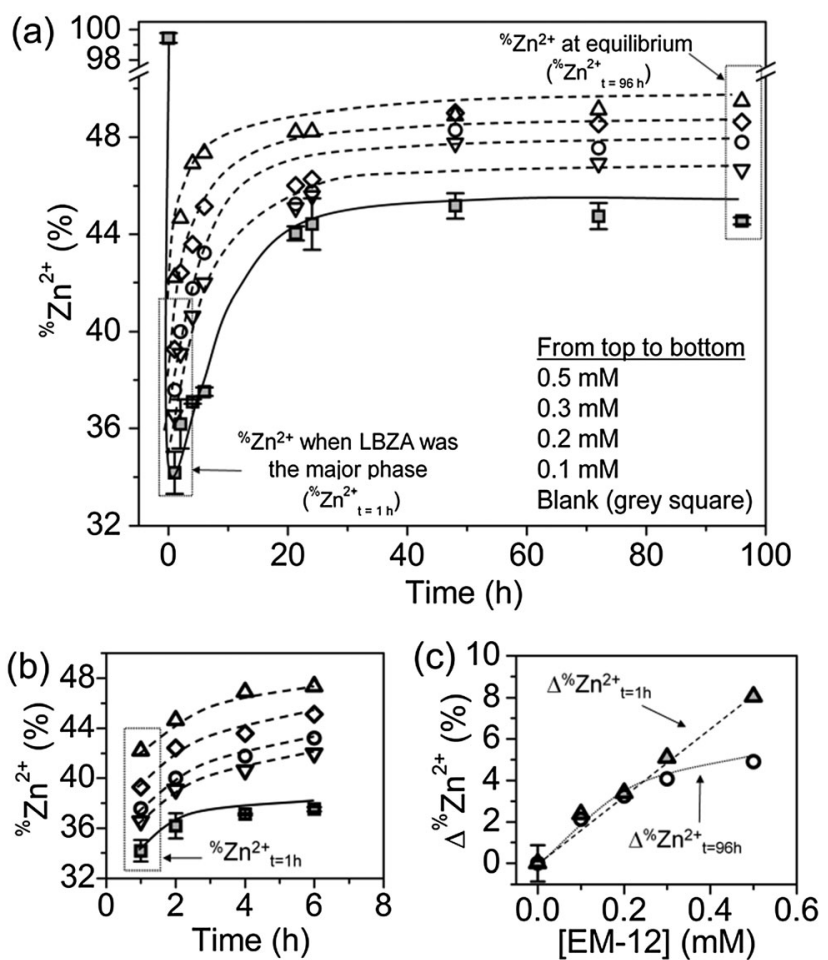

Fig. $6 \% \mathrm{Zn}^{2+}$, the percentage of $\mathrm{Zn}^{2+}$ in solution with respect to the initial $\mathrm{Zn}^{2+}$ concentration, for different EM-12 concentrations: ${ }^{\%} \mathrm{Zn}^{2+}$ as a function of reaction time (a) up to 96 hours and (b) up to 7 hours, and (c) $\Delta^{\%} \mathrm{Zn}^{2+}$ the difference between ${ }^{\%} \mathrm{Zn}^{2+}$ for the EM-12 added reaction and the blank, at $t=1$ hour ${ }^{\%} \mathrm{Zn}^{2+}{ }_{t=1 \mathrm{~h}}$ where LBZA was the major phase, grey triangle symbols) and $t=96$ hours ( $\% \mathrm{Zn}^{2+}{ }_{t=96 \mathrm{~h}}$ at equilibrium, circle symbols). selected time points $\left(\Delta^{\%} \mathrm{Zn}^{2+}{ }_{t=1 \mathrm{~h}}\right.$ and $\left.\Delta^{\%} \mathrm{Zn}^{2+}{ }_{t=96 \mathrm{~h}}\right)$ was calculated (Fig. 6c). $\Delta^{\%} \mathrm{Zn}^{2+}{ }_{t=1 \mathrm{~h}}$ and $\Delta^{\%} \mathrm{Zn}^{2+}{ }_{t=96 \mathrm{~h}}$ increased as a function of EM-12 (initial) concentration. The increase of ${ }^{\%} \mathrm{Zn}^{2+}$ in the presence of EM-12 started from the early stages of reaction while a positive correlation was observed between $\Delta^{\%} \mathrm{Zn}^{2+}$ and EM-12 concentration. These two observations suggest that EM-12 stabilized high concentrations of $\mathrm{Zn}^{2+}$ in solution with the stabilization starting from the beginning of the reaction.

If the higher concentration of $\mathrm{Zn}^{2+}$ present in solution was due to $\mathrm{Zn}^{2+}$ and EM-12 complexation, retention of EM-12 in solution would also be expected. The concentration of EM-12 in solution was measured using UV spectrometry. Absorbance calibration curves of the $\mathrm{ZnAc}_{2}-\mathrm{NH}_{3}$ system and for the peptides; EM-12 and EC-12, are available in ESI 3. $\dagger$ Almost complete retention of EM-12 in solution throughout the reaction was observed, (Fig. 7a), implying that either EM-12 only interacts with $\mathrm{Zn}^{2+}$ species in solution or interacts weakly (i.e. van der Waals forces) with zinc species in the solid phase (LBZs/ZnO), being released back into solution when a small force is applied to the system (such as centrifugation). The retention of EM-12 in the solution was further supported using FTIR analysis, since the spectra of 24 hour lyophilized precipitates did not show the characteristic peak of the amide-I band of EM-12 (Fig. 7b), in contrast to the behavior of EC-12 which will be discussed later.

\section{Comparison with EC-12; a peptide with higher complexation capability}

Up to this point, the delay formation effect shown by the addition of EM-12 to the ZnO-forming reaction was very different from the ZnO catalytic effect shown by GGGSC-tagged EM-12., ${ }^{9,16}$ This difference is believed to be due to the additional GGGSC tag present. Based on the side chain $\mathrm{p} K_{\mathrm{a}} \mathrm{s}$ calculated using Marvin, ${ }^{41}$ the charges of EM-12 and EC-12 side chains at pH 7.0 \pm 0.1 (ESI $4 \dagger)$ are summarized in Table 2 . For simplicity, only charges involving at least $50 \%$ ionization of the side chain of a peptide residue are shown. Over this narrow range of $\mathrm{pH}$ values, the side chain and termini charges of both peptides are nearly identical and their net charges are the same. Although only $\mathrm{E}_{1}$ and $\mathrm{P}_{12}$ are anionic, other residues such as histidine $(\mathrm{H})$, cysteine $(\mathrm{C})$, and methionine (M) are able to coordinate with $\mathrm{Zn}^{2+} \cdot{ }^{20,42,43}$ Histidine can bind to metal ions through its imidazole $\mathrm{N} \varepsilon 2$ or $\mathrm{N} \delta 1$ and become a bridging ligand when present in its deprotonated state. Although cysteine binds to metal ions most frequently in its deprotonated cysteinate form (i.e. deprotonated thiol group), a neutral cysteine is able to serve as a ligand in ferrous heme iron while non-deprotonable methionine can bind through its 

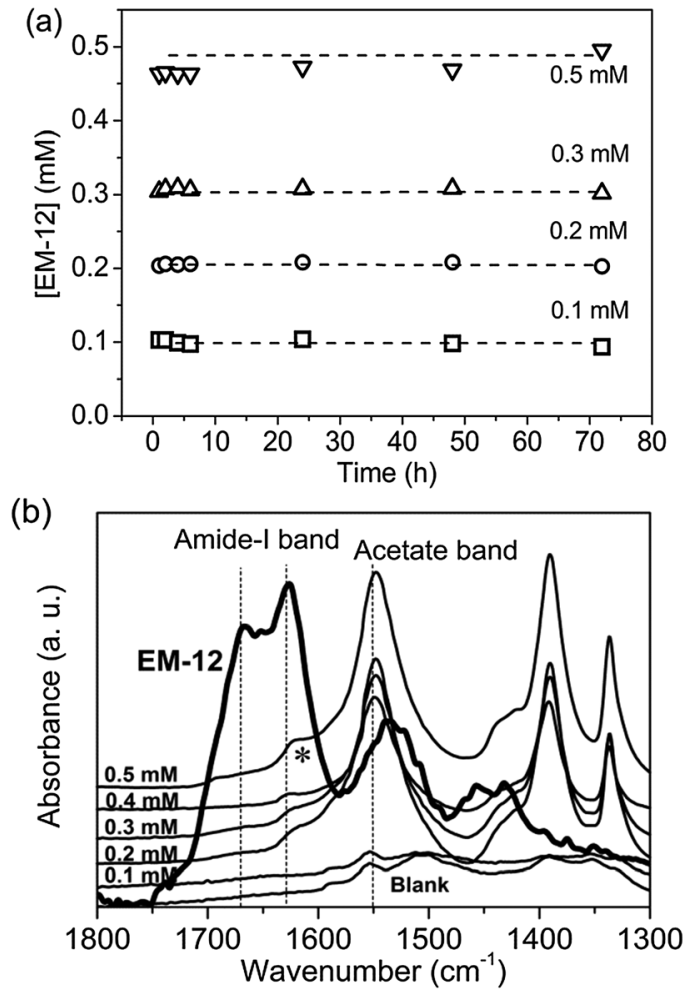

Fig. 7 (a) From UV-Vis, EM-12 concentration, [EM-12], in supernatants collected at different reaction time from reactions with initial [EM-12] of $0.1 \mathrm{mM}, 0.2 \mathrm{mM}, 0.3 \mathrm{mM}, 0.4 \mathrm{mM}$ and $0.5 \mathrm{mM}$ and (b) FTIR spectra of lyophilized precipitates collected at 24 hours. The peak arising with an asterisk (*) is attributed to the $\mathrm{O}-\mathrm{H}$ vibrational mode (corresponding to the hydroxide slab in LBZA). ${ }^{24}$

Table 2 The charges of EM-12 and EC-12 side chain functional groups calculated using Marvin ${ }^{44}$ at $\mathrm{pH} 7.0 \pm 0.1$ at $298 \mathrm{~K}$

EM-12 Sequence $E_{1} A_{2} H_{3} V_{4} M_{5} H_{6} K_{7} V_{8} A_{9} P_{10} R_{11} P_{12}$ Net charge Side chain charge - + + + + Terminal charge +

EC-12 sequence $\mathrm{E}_{1} \mathrm{~A}_{2} \mathrm{H}_{3} \mathrm{~V}_{4} \mathrm{C}_{5} \mathrm{H}_{6} \mathrm{~K}_{7} \mathrm{~V}_{8} \mathrm{~A}_{9} \mathrm{P}_{10} \mathrm{R}_{11} \mathrm{P}_{12}$ Net charge Side chain charge Terminal charge +

sulphur lone pair. ${ }^{20}$ Thus, it is conceivable that these two peptides are able to form complexes with $\mathrm{Zn}^{2+}$ thereby retaining more $\mathrm{Zn}^{2+}$ in solution than is possible in their absence. Since cysteine is known to be a stronger $\mathrm{Zn}^{2+}$ binder to $\mathrm{Zn}^{2+}$ compared to methionine, ${ }^{20}$ EC-12 was expected to retain more $\mathrm{Zn}^{2+}$ in solution compared to EM-12.

As anticipated, the addition of EC-12 to the $\mathrm{ZnAc}_{2}-\mathrm{NH}_{3}$ reaction under identical conditions retained more $\mathrm{Zn}^{2+}$ in solution throughout the reaction compared to EM-12 and the increase was proportional to the concentration of the EC-12 added (ESI $5 \dagger$ ). In the presence of EM-12 (0.1-0.5 mM), $\sim 36-42 \%$ and $\sim 46-50 \%$ of $\mathrm{Zn}^{2+}$ was retained in solution at $t=1$ hour and $t=96$ hours, respectively; compared to $34 \%$ and $45 \%$ for the Blank. In the presence of EC-12 at comparable concentrations, $\sim 37-47 \%$ of
$\mathrm{Zn}^{2+}$ was retained in solution at $t=1$ hour while $48-57 \%$ was retained at $t=96$ hours. The higher $\mathrm{Zn}^{2+}$-complexation capability by EC-12 may be caused either by cysteine being a stronger binder compared to methionine and/or by the difference in the conformation of the peptides in solution. The comparison of structures simulated in water at $300 \mathrm{~K}$ (GROMACS, force field: GROMOS95, $\mathrm{d} t: 0.002 \mathrm{ps}$, total time: $2 \mathrm{~ns})^{45}$ using Visual Molecular Dynamics (VMD) ${ }^{46}$ in Fig. 8 showed that EM-12 (red structure) and EC-12 (blue structure) have a highly superimposable C-termini segment (same peptide sequence). However, the structure of EM-12 containing methionine at position 5 is more compact than EC-12 having a cysteine at position 5, even though their side chain functionalities are highly similar. It is also possible that the more extended glutamic acid (marked by a black arrow in Fig. 8) at the N-terminal having an anionic side chain may contribute to the higher complexation of $\mathrm{Zn}^{2+}$ in solution with EC-12 compared to EM-12.

In contrast to complete retention of EM-12 in solution throughout the reaction (Fig. 7a), 40-75\% of the added EC-12 was absent from the solution at the beginning of the reaction (Fig. 9a). The complete retention of EC-12 in solution occurred within $\sim 7$ hours of reaction for the $0.1 \mathrm{mM}$ EC-12 precipitate, $\sim 24$ hours for $0.2-$ $0.3 \mathrm{mM} \mathrm{EC}-12$ and $\sim 30$ hours for $0.5 \mathrm{mM} \mathrm{EC}-12$. In agreement with the different starting time points for complete retention, the amide-I band (FTIR) could be detected for the 24 hour precipitates when higher concentration of EC-12 were added (Fig. 9b), but not when EM-12 was added (Fig. 7b).

The detection of EC-12 in the precipitate was also shown by XPS. The sample with $0.4 \mathrm{mM}$ EC-12 was chosen for analysis due to the prior detection of peptide by FTIR. The XPS survey spectrum, Fig. 10a, was similar to that observed when studying EM-12 (Fig. 3a); however, it not only showed the presence of Zn, $\mathrm{O}$ and $\mathrm{C}$, but also $\mathrm{N}$. The high resolution core level spectrum of the $\mathrm{N}$ 1s region gave a peak at $399.6 \mathrm{eV}$ (Fig. 10b), attributed to the presence of amino groups in the peptide $(399.0 \pm 0.3 \mathrm{eV}) .^{22}$ The $\mathrm{C} 1 \mathrm{~s}$ core level region also showed a peak at $286.5 \mathrm{eV}$, Fig. 10c, corresponding to the tertiary carbon connected with the nitrogen atom of the amino group, ${ }^{4-49}$ which was not detected in precipitates containing EM-12 (Fig. 4c).



Fig. 8 Visualization of the superimposition of molecular structures (simulated in water at $300 \mathrm{~K}$ ) for EM-12 (EAHVMHKVAPRP) in red, EC-12 (EAHVCHKVAPRP) in blue, and G-12 (GLHVMHKVAPPR) in orange; images generated using VMD. ${ }^{46}$ 

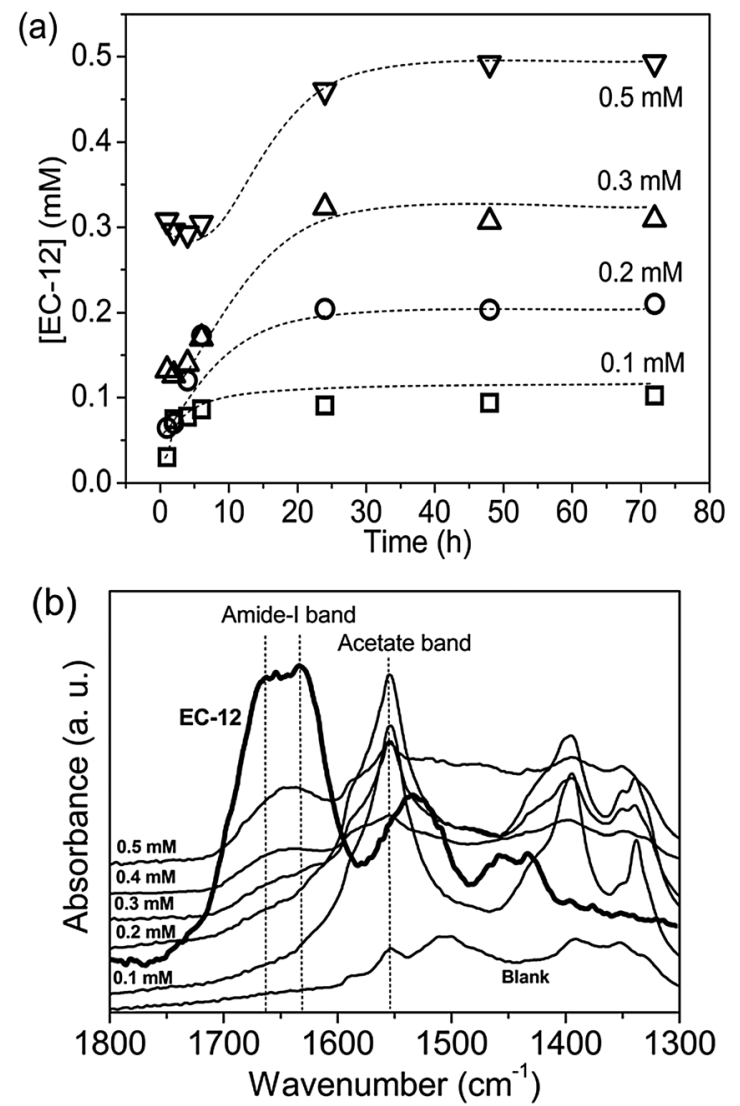

Fig. 9 (a) EC-12 concentration, [EC-12], in supernatants collected at different reaction time from reaction with initial [EC-12] of $0.1 \mathrm{mM}$, $0.2 \mathrm{mM}, 0.3 \mathrm{mM}$ and $0.5 \mathrm{mM}$ from UV-vis measured (b) FTIR spectra of precipitates collected at 24 hours.
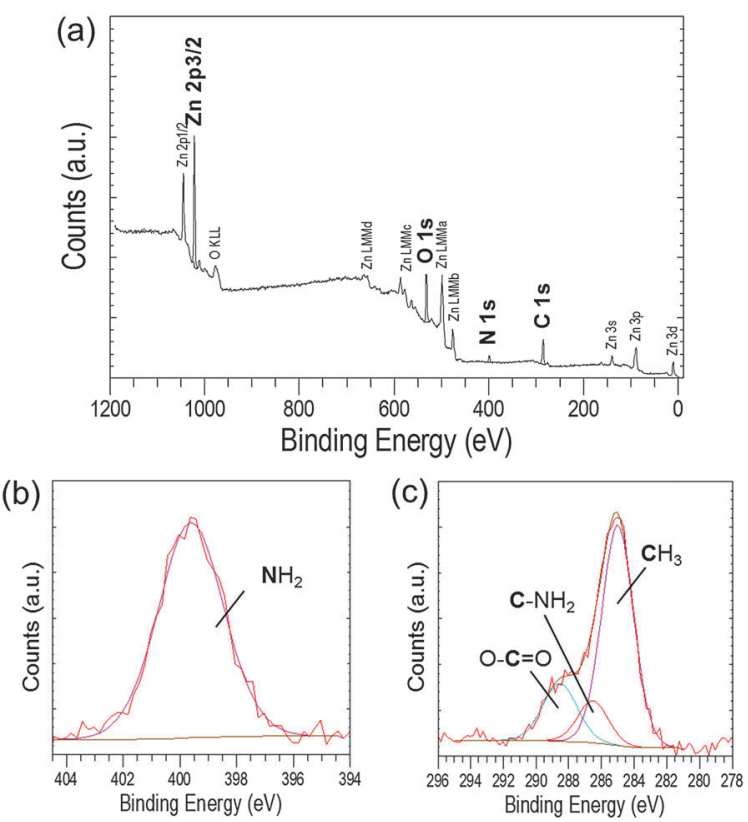

Fig. 10 (a) XPS survey spectrum recorded from an as-deposited precipitate collected at 24 hours ([EC-12] at $0.4 \mathrm{mM}$ ) and the corresponding high resolution core level spectra of (b) $\mathrm{N}$ 1s and (c) $\mathrm{C}$ 1s regions.



Fig. 11 XPS high resolution core level spectra of the $S 2 p$ region.

Further, a broad peak was observed in the $\mathrm{S} 2 \mathrm{p}$ region, which could arise from the cysteine thiol group ${ }^{50}$ present in EC- 12 . The broad peak at around $162.2 \mathrm{eV}$ (Fig. 11) was deconvoluted into two peaks, $2 \mathrm{p}_{3 / 2}$ and $2 \mathrm{p}_{1 / 2}$ at 161.8 and $163.0 \mathrm{eV}$, respectively. The $S$ 2p doublet separation could be fitted using a peak area ratio of $2: 1$ and a separation of $1.18 \mathrm{eV}$. The overlap of the two peaks was most likely due to the small amount of sulphur in the samples. Previous studies have showed that the binding energy of the $S 2 p_{3 / 2}$ signal determines the presence of sulphur as a thiol (unbound) or thiolate (bound to the surface), the BE values being at $\sim 163 \mathrm{eV}$ and $\sim 162 \mathrm{eV}$, respectively. ${ }^{47,48,50-52}$ Our data suggests that the interaction of EC-12 with the solidphase was via $\mathrm{Zn}^{2+}$-sulphur (from cysteine). Despite the presence of a sulphur atom in both peptides, methionine for EM-12 and cysteine for EC-12, the higher complexation capability of EC-12 seems to be at least in part due to the presence of the thiol group in cysteine.

From the characterization of the 24 hour precipitate formed in the presence of EC-12, ZnO was the main crystalline phase detected by XRD (ESI $6 \dagger$ ). However, as the weight loss of this precipitate by TGA was $25 \%$, the experimental data suggests that LBZA was also present in the solid phase. Thus, the precise solid phase(s), LBZA and/or ZnO, with which EC-12 interacted, cannot be uniquely identified. Based on XRD and TGA results (ESI $6 \dagger$ ), the higher complexation capability of EC-12 did not lead to a stronger delay/suppression effect than EM-12 on ZnO formation when higher concentrations of peptide were added. From comparison of the \% thermal decomposition weight loss, generally all 24 hour precipitates obtained in the presence of EC-12 contained a higher fraction of $\mathrm{ZnO}$ (weight loss 25\%) compared to those obtained in the presence of EM-12 (weight loss $\sim 34 \%$ ), and no ZnO suppression effect was observed at the highest EC-12 concentration employed (Fig. 12). However, a weaker but still delayed-formation of $\mathrm{ZnO}$ due to the presence of EC-12 was remarkably caused when lower concentrations of EC-12 were used (ESI $4 \dagger$ ). That EC-12 is able to interact with species in solution and also with species in the solid state is the key to this behavior. According to Umetsu et al., ET-17 could catalyze $\mathrm{ZnO}$ formation from a stable $\mathrm{Zn}(\mathrm{OH})_{2}$ sol. ${ }^{9}$ Although EC-12 did not demonstrate any catalytic capability as shown by ET-17, its weaker delay/suppression effect on $\mathrm{ZnO}$ formation (compared to EM-12) suggests the possibility of there being a 
balance between a catalytic effect and a delay/suppression effect by the modification of EM-12 through the incorporation of a cysteine residue in the peptide. This (effects tuning) possibility cannot be discounted because (i) EM-12, EC-12 and ET-17 have the same/highly similar combination of amino acid side chain functionalities and (ii) any structural differences arising from peptide sequence may be used to tune the strength of these effects. In terms of crystal morphology (Fig. 12), ZnO crystals formed at 24 hours were mostly twinned but asymmetrical. Crystals formed in the presence of 0.1-0.2 mM EC-12 have more defined facets (Fig. 12a and b) while those formed at higher EC-12 concentrations assumed the shape of mushrooms (Fig. 12c and d). When the reaction was extended to 48 hours, the asymmetrical crystals developed into more symmetrical crystals with smaller diameter at their twinned planes, having either a dumbbell shape (Fig. 12e and f) or an hourglass-like shape (Fig. 12g and $\mathrm{h}$ ). It is noticeable that these $\mathrm{ZnO}$ crystals were morphologically different from those obtained from the Blank reaction that had uniform diameters along their $c$-axes.
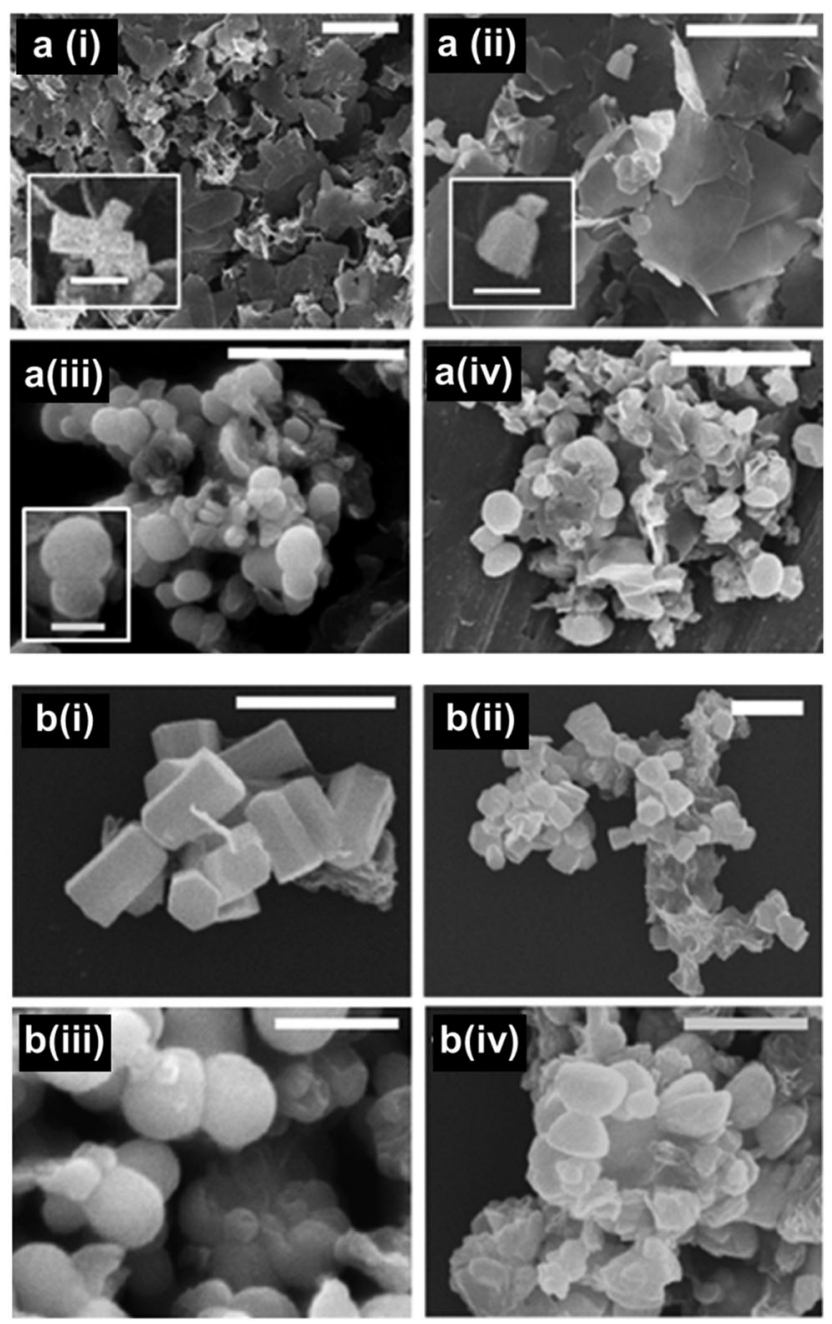

Fig. 12 SEM images of precipitates collected at (a) 24 hours (scale bars = $5 \mu \mathrm{m}$, inset scale bars $=1 \mu \mathrm{m}$ ) and (b) 48 hours (scale bar $=2 \mu \mathrm{m}$ ). EC-12 concentration for SEM images are (i) $0.1 \mathrm{mM}$ for (ii) $0.2 \mathrm{mM}$, (iii) $0.4 \mathrm{mM}$ and (iv) $0.5 \mathrm{mM}$.

\section{Effects of EM-12 and EC-12 on ZnO morphology}

In the presence of EM-12, $\mathrm{ZnO}$ crystals generally transformed from symmetrical twinned $\mathrm{ZnO}$ crystals (Blank) to asymmetric twinned crystals (in the majority) followed by un-twinned crystals as EM-12 concentration was increased from $0.1 \mathrm{mM}$ to $0.4 \mathrm{mM}$, Fig. 13(a)-(c) and Scheme 1a. The aspect ratio was studied for all $\mathrm{ZnO}$ containing precipitates and showed the reduction of $L / D$ with the addition of peptide (Fig. 14). For the Blank (0 $\mathrm{mM}$ of EM-12) the points are overlapped due to the symmetrical hexagonal rods and for $[\mathrm{EM}-12] \geq 0.3 \mathrm{mM}$ only one value is given due to the crystal growth equilibrated before/at the end of growth of the first rod. Further, EM-12 not only caused the delayed formation of $\mathrm{ZnO}$ (conversion from LBZA to $\mathrm{ZnO}$ ) but also caused the inhibition of crystal growth as seen in Fig. 14 (inset), where the Blank increased its aspect ratio with time and for samples containing EM-12 the aspect ratio was maintained over time. In the presence of EC-12, a similar trend to the Blank was observed, which suggested that addition of EC-12 did not lead to an inhibition of crystal growth as seen for EM-12.

ZnO crystals generated in the presence of EC-12, Scheme 1b, were different from those obtained in the presence of EM-12 in three aspects. Firstly, all crystals remained twinned as the


Fig. 13 SEM images of precipitates collected at 48 hours for: (a) $0.1 \mathrm{mM}$, (b) $0.2 \mathrm{mM}$, and (c) $0.4 \mathrm{mM}$ of EM-12. All scale bars are $5 \mu \mathrm{m}$ and inset scale bars at $0.5 \mu \mathrm{m}$.



Scheme 1 The illustration of $\mathrm{ZnO}$ morphology (principal) in the presence of (a) EM-12 at different concentrations (based on 48 hour-precipitates) and, (b) EC-12 at different concentrations collected after 24 hours and 48 hours. Non-scaled images are for morphology comparisons only. 


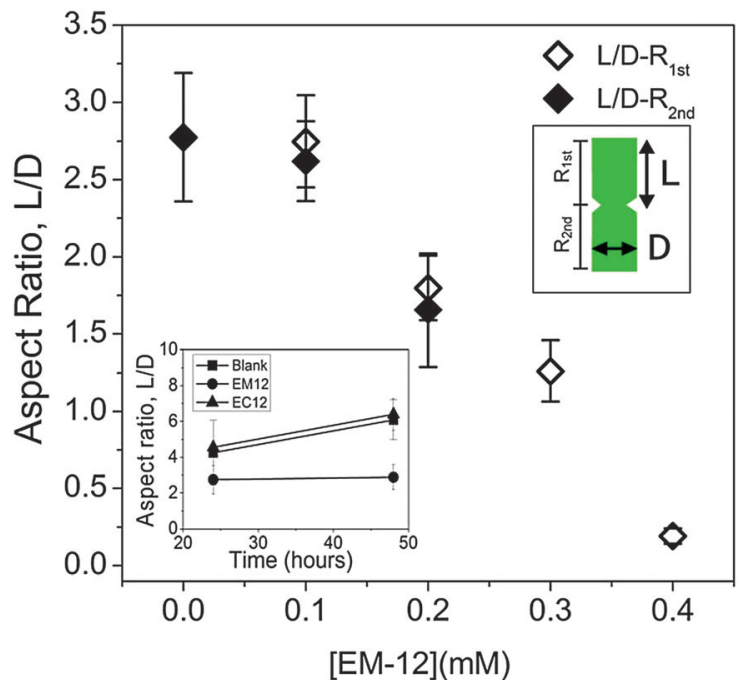

Fig. 14 Average aspect ratio (L/D) of $\mathrm{ZnO}$ crystal rods $(n \geq 30)$ as a function of [EM-12] where large and small indicated on the legend represent the larger or smaller crystal on each side of the twin plane. The inset shows the $L / D$ of entire $\mathrm{ZnO}$ crystals $(n \geq 30)$ as a function of time for Blank, EM-12 and EC-12 samples.

EC-12 concentration was increased. Secondly, the diameter of the crystals was not uniform along their $c$-axis. Thirdly, the surface planes of the crystals became less well-defined with increasing EC-12 concentration with mushroom-like ZnO crystals being obtained in the presence of higher concentrations of EC-12.

It has been proposed that twinned hexagonal rods are formed by the aggregation of two approximately spherical particles. ${ }^{53}$ However, the observed morphology changes (with time) in the presence of EC-12 suggest that crystallization occurred by the formation of the first hexagonal $\operatorname{rod}\left(\mathrm{R}_{1 \mathrm{st}}\right)$ followed by the growth of the second $\operatorname{rod}\left(\mathrm{R}_{2 \mathrm{nd}}\right)$ on the first one. ${ }^{15}$ Note that with the increase of EC-12 the hexagonal rods became spheres $\left(S_{1 \text { st }}\right.$ and $\left.S_{2 n d}\right)$. It is believed that EM-12 added reactions follow the same mechanism. It has been reported that the reduction of the aspect ratio on crystals can be due by specific polypeptides playing a role in the competitive adsorption-nucleation process by interacting with specific crystal planes ${ }^{15}$ and for $\mathrm{ZnO}$, theoretical and experimental studies, ${ }^{12,15}$ have suggested that polypeptides can interact with the (0002) plane corresponding to the $c$-axis with a reduction in the aspect ratio being observed; however, in this current work, the changes in twinning behavior with increasing amount of EM-12 can be explained as follows. $\mathrm{Zn}^{2+}$-EM-12 complexation reduced the amount of $\mathrm{Zn}^{2+}$ available for crystal growth. At lower EM-12 concentrations (0.1-0.2 mM), the growth of the second $\operatorname{rod}\left(\mathrm{R}_{2 \mathrm{nd}}\right)$ was not complete resulting in the formation of asymmetrically twinned $\mathrm{ZnO}$ crystals. In the presence of 0.3 and $0.4 \mathrm{mM}$ EM-12, crystal growth equilibrated before/at the end of growth of the first $\operatorname{rod}\left(\mathrm{R}_{1 \mathrm{st}}\right)$, thus, untwinned $\mathrm{ZnO}$ crystals were obtained, which was supported by the observation of untwinned crystals being shorter but having comparable diameters with those (larger side of asymmetrical twinned crystals) formed at lower EM-12 concentrations (Fig. 14).
Addition of $\mathrm{R}_{2 \text { nd }}$ can be considered as a secondary nucleation process $^{15}$ which in this case was inhibited by the presence of EM-12.

The $\mathrm{ZnO}$ morphology transformation (from dumbbell to mushroom-like) by increasing EC-12 concentration is believed to be due to interaction with the solid-phase. This peptide may have modified the $\mathrm{ZnO}$ morphology via reversible adsorption on ZnO crystals. ${ }^{54}$ The adsorption of G-12 (GLHVMHKVAPPR), ${ }^{8}$ a highly similar ZnO-BP (67\% and 58\% similar to EM-12 and EC-12, respectively), has been shown to reduce the aspect ratio of ZnO crystals via an adsorption-growth inhibition mechanism by interacting with $\mathrm{Zn}^{2+}$ and/or $\mathrm{O}^{2-}$ on $\mathrm{ZnO}$ surfaces. ${ }^{12}$ The differences and similarities between the effects of EM-12, EC-12 and G-12 on ZnO crystal morphology and formation may have arisen (i) at least partly from the presence of glutamic acid (E) in EM-12 and EC-12 but not in G-12; (ii) their superimposable C-termini, (iii) superimposable N-termini between EC-12 and G-12, and (iv) the extended structure of EC-12 in solution as opposed to the more compact structure of EM-12, Fig. 8.

The modification of $\mathrm{ZnO}$ morphology via the reversible adsorption of EC-12 on ZnO crystals cannot be confirmed due to the presence of other solid phase(s), LBZs. The interlayer spacing of LBZA formed in the presence of EC-12 did not change significantly compared to the Blank (ESI 6†) which implied that either EC-12 was not intercalated or it was oriented parallel to the zinc hydroxide layer while intercalated. Thus, the possibility of EC-12 intercalating into LBZA formed and then released back into the solution during LBZA conversion to $\mathrm{ZnO}$ cannot be discounted.

A recent study has shown that some common amino acids can be incorporated into the $\mathrm{ZnO}$ lattice, ${ }^{55}$ particularly, amino acids containing $\mathrm{S}$ or Se, as is the case of cysteine and selenocysteine, respectively. Subsequently, it was found that incorporation of the amino acids led to a change in the optical and paramagnetic properties of the material as well as the crystal morphology. The possibility that EC-12 could have been incorporated into the lattice of $\mathrm{ZnO}$ was studied, ESI. $\dagger \mathrm{ZnO}$ lattice strain modification was observed when EC-12 was added into the system further suggesting the possibility of this peptide being incorporated into the lattice of $\mathrm{ZnO}$.

\section{Experimental}

\section{Materials and methods}

Reagents. Zinc acetate $\left(\mathrm{Zn}\left(\mathrm{CH}_{3} \mathrm{COO}\right)_{2}\right)$, piperazine $\left(\mathrm{C}_{4} \mathrm{H}_{10} \mathrm{~N}_{2}\right)$, $N, N$-diisopropylethylamine (DIPEA, $\mathrm{C}_{8} \mathrm{H}_{19} \mathrm{~N}$ ), trifluoroacetic acid (TFA, $\left.\mathrm{C}_{2} \mathrm{HF}_{3} \mathrm{O}_{2}\right)$, thioanisole $\left(\mathrm{C}_{7} \mathrm{H}_{8} \mathrm{~S}\right)$, 3,6-dioxa-1,8-octanedithiol (DODT, $\mathrm{C}_{6} \mathrm{H}_{14} \mathrm{O}_{2} \mathrm{~S}_{2}$ ), $1 \mathrm{M}$ hydrochloride acid ( $\mathrm{HCl}$ ), zinc atomic absorption standard solution (1000 ppm), $1 \mathrm{M}$ potassium hydroxide volumetric standard ( $\mathrm{KOH})$, acetonitrile (ACN) and sodium chloride $(\mathrm{NaCl})$ were purchased from Sigma-Aldrich; ammonia solution $\left(\mathrm{NH}_{3}, 35 \%\right)$, ethanol $\left(\mathrm{C}_{2} \mathrm{H}_{6} \mathrm{O}\right), N, N$-dimethylformamide (DMF), dichloromethane (DCM), $N$-methyl-2-pyrrolidinone (NMP), and diethyl ether were purchased from Fisher Scientific; $O$-benzotriazole- $N, N, N^{\prime}, N^{\prime}$-tetramethyl-uronium-hexafluoro-phosphate 
(HBTU) and all Fmoc-protected amino acids required for peptide synthesis were purchased from CEM Corporation while the proline-preloaded-TGT resins were obtained from Novabiochem ${ }^{\circledR}$. All chemicals were used without further treatment. Distilleddeionized water $\left(\mathrm{ddH}_{2} \mathrm{O}\right)$ with conductivity less than $1 \mu \mathrm{S} \mathrm{cm} \mathrm{cm}^{-1}$ was used as the solvent for all $\mathrm{ZnO}$ synthesis reactions.

ZnO synthesis and kinetics studies. ZnO synthesis was conducted in aqueous solution following a previously described method $^{32}$ in which twinned hexagonal rods were expected to grow using $30 \mathrm{mM}$ of $\mathrm{Zn}\left(\mathrm{CH}_{3} \mathrm{COO}\right)_{2}$ (hereafter labeled as $\mathrm{ZnAc}_{2}$ ) in $50{ }^{\circ} \mathrm{C}$ water and $31.25 \mathrm{mM}$ of $\mathrm{NH}_{3}$. To avoid deviation of $\mathrm{NH}_{3}$ concentration from the target concentration by evaporation, the concentration of a $5 \% \mathrm{NH}_{3}$ solution used for stock solution preparation was determined by titration prior to each experiment. For all reactions, $24 \mathrm{ml}$ of $31.25 \mathrm{mM}$ of $\mathrm{NH}_{3}$ stock solution at room temperature was vigorously stirred into $25 \mathrm{ml}$ of $30 \mathrm{mM} \mathrm{ZnAc}_{2}$ solution (at $50{ }^{\circ} \mathrm{C}$ ) followed by the addition of $1 \mathrm{ml}$ of the prepared peptide solutions; giving final peptide concentrations in a range of $0-0.5 \mathrm{mM}$. The $\mathrm{pH}$ of the reaction solutions were $7.0 \pm 0.1$ regardless of the peptide identity and the concentration of the peptide used. The mixtures were placed in a water-bath set at $50{ }^{\circ} \mathrm{C}$ for up to 168 hours. During the course of reaction, sample aliquots of $5 \mathrm{ml}$ were taken from the reaction vessels at 24 and 48 hours ( \pm 2 minutes). From detailed studies of the Blank reaction, ${ }^{31} \mathrm{ZnO}$ was detected as the major phase at 16 hours and beyond. Thus, times chosen were to enable the formation of $\mathrm{ZnO}$ to be followed. Collected samples were centrifuged at $13000 \mathrm{rpm}$ for 3 minutes to separate precipitates from the supernatants. The precipitates were washed three times with $\mathrm{ddH}_{2} \mathrm{O}$. The supernatant obtained was recentrifuged using the same conditions. This supernatant was used for the determination of the concentration of $\mathrm{Zn}^{2+}$ and peptide in the solution. Cleaned precipitates and selected supernatants were lyophilized at $-70{ }^{\circ} \mathrm{C}$ using a Virtis-110 freeze-dryer.

Solid phase peptide synthesis. EM-12 and EC-12 were prepared by solid phase methods using a microwave-assisted solid phase peptide synthesizer (CEM Corporation) via Fmoc chemistry. ${ }^{56}$ TGT resin preloaded with Fmoc-protected proline was used as the solid support. The following side chain protections were used: Pbf for arginine; Trt for cysteine and histidine; OtBu for glutamic acid; and Boc for lysine. The couplings, via a $O$-benzotriazole- $N, N, N^{\prime}, N^{\prime}$-tetramethyl-uroniumhexafluoro-phosphate (HBTU) condensation agent, were single except for arginine where a double coupling was used. The cleavage of the peptide from the resin and the deprotection of side chains were achieved in one step by treating the peptide resin with a cleaving agent containing trifluoroacetic acid, thioanisole, $\mathrm{dd}_{2} \mathrm{O}$, and 3,6-dioxa-1,8-octanedithiol (DODT). The cleaved peptides were re-precipitated in chilled diethyl ether and washed three times with the same solvent prior to lyophilisation at $-70{ }^{\circ} \mathrm{C}$ using a Virtis-110 freeze-dryer. The purity of the lyophilized peptides was analyzed with a Dionex HPLC equipped with a UV detector (set at $214 \mathrm{~nm}$ ) and a Jupiter 4u Proteo 90A C12 Reverse Phase column (Phenomenex). The purity of EM-12 and EC-12 was determined as $88 \%$ and
93\% respectively. The mass to charge ratio $(\mathrm{m} / \mathrm{z})$ of the peptides was measured using a Bruker UltraflexIII TOF/TOF mass spectrometer and analysed with BrukerDaltonics flexAnalysis software. The molecular weight $\left(M_{\mathrm{w}}\right)$ of EM-12 and EC-12, $1371.6 \mathrm{~g} \mathrm{~mol}^{-1}$ and $1343.6 \mathrm{~g} \mathrm{~mol}^{-1}$, respectively; was confirmed with their measured $\mathrm{m} / \mathrm{z}$ of $1371.8 \mathrm{~m} / \mathrm{z}$ and $1343.7 \mathrm{~m} / \mathrm{z}$, respectively (ESI $8 \dagger$ ).

Characterization of lyophilized precipitates. The crystallinity of the precipitates obtained was characterized using XRD (PANalytical X'Pert PRO, $\mathrm{Cu} \mathrm{K} \alpha$ radiation with wavelength of $1.54056 \AA$ ). Ground samples (if necessary) were packed into an aluminium sample holder and scanned from $5^{\circ}$ to $90^{\circ}$ of $2 \theta$ at an accelerating voltage of $45 \mathrm{kV}, 40 \mathrm{~mA}$ filament current, using a scan speed of $0.02^{\circ} \mathrm{s}^{-1}$ at room temperature. Diffraction patterns were analyzed using X'Pert-HighScore Plus (Version 2.0a) program for diffractogram manipulation, background determination and peak identification. The morphology and size of selected precipitates were studied using SEM (JEOL JSM$840 \mathrm{~A}, 20 \mathrm{kV}$, gold sputter-coated samples). For ZnO crystal size analysis, more than 30 crystals were studied for each sample and the aspect ratio $(L / D=$ length/diameter average) of each individual crystal was determined using the Java-based image processing program (ImageJ software). FTIR (Perkin Elmer Spectrum 100 FTIR Spectrometer with Diamond/KRS-5 crystal and Nicolet Magna IR-750) was used to detect the functional groups present in the lyophilized precipitates. Spectra were averaged from 32 scans at $2 \mathrm{~cm}^{-1}$ resolution with air as background. The amount of non-ZnO component in the precipitates was determined by thermogravimetric analysis, TGA (Mettler Toledo TGA/SDTA $851^{\mathrm{e}}$ ) where samples were heated at $10^{\circ} \mathrm{min}^{-1}$ from $30{ }^{\circ} \mathrm{C}$ to $900{ }^{\circ} \mathrm{C}$ in air to ensure complete combustion of all organic material. The chemical constitution of the precipitates was investigated by XPS using a VG Scientific ESCALab MkII X-Ray photoelectron spectrometer with a $\mathrm{Al} \mathrm{K} \alpha$ X-ray source $(h \nu=1486.6 \mathrm{eV})$. Samples were ground and then mounted on standard sample holders. Before analysis of the samples, the calibration and linearity of the binding energy scale was checked with a pure silver sample using the peak positions of the $\mathrm{Ag} 3 \mathrm{~d}_{5 / 2}$ photoelectron line (at $368.26 \mathrm{eV}$ ) and the $\mathrm{AgM}_{4} \mathrm{NN}$ Auger line (at $1128.78 \mathrm{eV}$ ). Survey spectra of precipitates were collected covering the full binding energy (BE) range from $0-1200 \mathrm{eV}$ using a step size of $1 \mathrm{eV}$, a dwell time of 0.2 seconds and a pass energy (PE) of $50 \mathrm{eV}$. High resolution core level spectra of the $\mathrm{Zn} 2 \mathrm{p}_{3 / 2}, \mathrm{C} 1 \mathrm{~s}, \mathrm{O} 1 \mathrm{~s}, \mathrm{~N} 1 \mathrm{~s}$ and $\mathrm{S} 2 \mathrm{p}$ peaks were collected using a PE of $20 \mathrm{eV}$, a step size of 0.2 and a dwell time of 0.4 seconds, which were subsequently deconvoluted and fitted using standard mixed Gaussian-Lorentzian components using CasaXPS software. To compensate for surface charging effects in the insulating samples, all binding energies were corrected with reference to the saturated hydrocarbon $\mathrm{C}$ 1s peak at 285.0 eV using the CasaXPS software.

Detection of peptide in supernatant. $200 \mu \mathrm{l}$ of the supernatant was diluted ten times with $\mathrm{ddH}_{2} \mathrm{O}$, placed in a quartz cuvette (10 $\mathrm{mm}$ path length), and scanned at $214 \mathrm{~nm}$ using a Unicam UV2 UV-VIS spectrophotometer. The absorbance of EM-12 or EC-12 in the supernatant was determined by subtracting 
the absorbance arising from $\mathrm{ZnAc}_{2}$ and $\mathrm{NH}_{3}$ from the absorbance of the supernatant. The absorbance of $\mathrm{ZnAc}_{2}$ at $214 \mathrm{~nm}$ was estimated from the calibration curve for $\mathrm{ZnAc}_{2}$ absorbance using $\left[\mathrm{Zn}^{2+}\right]$ measured by ICP-OES while a constant absorbance value was deducted for $\mathrm{NH}_{3}$. The concentration of EM-12 and EC-12 were determined by comparing the absorbance of the peptide against a series of calibration peptide solutions prepared in the same medium (ESI $3 \dagger$ ). FTIR-ATR (Perkin Elmer Spectrum 100 FTIR Spectrometer with Diamond/KRS-5 crystal) was used to detect the presence of amide-I and amide-II bands of peptides in the lyophilized supernatants. Spectra were averaged from 32 scans collected at $2 \mathrm{~cm}^{-1}$ resolution with air as background.

Detection of $\mathrm{Zn}^{2+}$ in the supernatant. $100 \mu \mathrm{l}$ of the supernatant was diluted a hundred times with $0.9 \% \mathrm{HCl}$ solution and the concentration of $\mathrm{Zn}^{2+}$ determined using ICP-OES, Perkin Elmer Optima 2100DV. Standard solutions with known concentrations were prepared in triplicate to generate the calibration curve.

\section{Conclusions}

The effect of the peptides EM-12 and EC-12 during ZnO formation via the $\mathrm{ZnAc}_{2}-\mathrm{NH}_{3}$ reaction, showed that the presence of the peptide EM-12 causes a delay and/or suppression of $\mathrm{ZnO}$ formation when the peptide concentration was increased, with LBZA being the major compound present at the highest concentration of EM-12 added. Further, the presence of EM-12 not only caused the delayed formation of $\mathrm{ZnO}$ (conversion from LBZA to $\mathrm{ZnO}$ ) but it also caused the inhibition of crystal growth (wurtzite structured hexagonal rods) along the $c$-axis ((0002) plane). The presence of EC-12; however, caused a more drastic change in the mineral morphology with mushroom-like ZnO crystals being formed, and remarkably, no ZnO suppression was observed for the highest EC-12 concentrations added.

The data presented appears to show that the mechanism of ZnO crystallisation occurs by the formation of a first hexagonal $\operatorname{rod}\left(\mathrm{R}_{1 \mathrm{st}}\right)$ followed by the growth of a second $\operatorname{rod}\left(\mathrm{R}_{2 \mathrm{nd}}\right)$ on the first one, considering the addition of $\mathrm{R}_{2 \mathrm{nd}}$ as a secondary nucleation process.

Experimental data showed that EM-12 interacts with $\mathrm{Zn}^{2+}$ species in solution, whereas EC-12 interacts either with $\mathrm{Zn}^{2+}$ species in solution and in the solid phase(s). Peptide interaction with the solid-phase cannot be observed when using EM-12 although weak interactions cannot be discounted. The EC-12 interaction mechanism is proposed to include $\mathrm{Zn}^{2+}$ sulphur (from cysteine) interactions. Further, the reduction of the amount of $\mathrm{Zn}^{2+}$ in solution in the presence of EM-12 was not the only cause for the delayed/suppression of $\mathrm{ZnO}$ formation in the $\mathrm{ZnAc}_{2}-\mathrm{NH}_{3}$ reaction, since a higher $\mathrm{Zn}^{2+}$-EC-12 complexation compared with EM-12 was observed. ZnO lattice strain modification was observed when EC-12 was added into the system and it is suggested that this peptide may be incorporated into the lattice of $\mathrm{ZnO}$.

\section{Acknowledgements}

We are very grateful to the U.S. Air Force Office of Scientific Research (AFOSR) for funding (FA9550-13-1-0040 and FA955006-1-0154). We thank Dr G. Hickman for the help with Mass spec analysis, Dr Olivier Deschaume for computational studies and Dr Marion Limo for her knowledge in this field.

\section{Notes and references}

1 S. Mann, Biomimetic Materials Chemistry, VCH, New York, 1996.

2 S. V. Patwardhan, S. J. Clarson and C. C. Perry, Chem. Commun., 2005, 1113-1121.

3 A. Xu, Y. Ma and H. Coelfen, J. Mater. Chem., 2007, 17, 415-449.

4 C. Sanchez, H. Arribart and M. M. Guille, Nat. Mater., 2005, 4, 277-288.

5 Z. R. Tian, J. A. Voigt, J. Liu, B. McKenzie and M. J. McDermott, J. Am. Chem. Soc., 2002, 124, 12954-12955.

6 C. K. Thai, H. X. Dai, M. S. R. Sastry, M. Sarikaya, D. T. Schwartz and F. Baneyx, Biotechnol. Bioeng., 2004, 87, 129-137.

7 K. Kjaergaard, J. K. Sorensen, M. A. Schembri and P. Klemm, Appl. Environ. Microbiol., 2000, 66, 10-14.

8 M. M. Tomczak, M. K. Gupta, L. F. Drummy, S. M. Rozenzhak and R. R. Naik, Acta Biomater., 2009, 5, 876-882.

9 M. Umetsu, M. Mizuta, K. Tsumoto, S. Ohara, S. Takami, H. Watanabe, I. Kumagai and T. Adschiri, Adv. Mater., 2005, 17, 2571-2575.

10 D. Rothenstein, B. Claasen, B. Omiecienski, P. Lammel and J. Bill, J. Am. Chem. Soc., 2012, 134, 12547-12556.

11 P. Golec, J. Karczewska-Golec, M. Łoś and G. Wgrzyn, J. Nanopart. Res., 2012, 14, 1-6.

12 M. Liang, O. Deschaume, S. V. Patwardhan and C. C. Perry, J. Mater. Chem., 2011, 21, 80-89.

13 M. J. Limo, R. Ramasamy and C. C. Perry, Chem. Mater., 2015, 27, 1950-1960.

14 T. Togashi, N. Yokoo, M. Umetsu, S. Ohara, T. Naka, S. Takami, H. Abe, I. Kumagai and T. Adschiri, J. Biosci. Bioeng., 2011, 111, 140-145.

15 M. Muthukumar, J. Chem. Phys., 2009, 130, 161101.

16 H. Bai, F. Xu, L. Anjia and H. Matsui, Soft Matter, 2009, 5, 966-969.

17 N. Yokoo, T. Togashi, M. Umetsu, K. Tsumoto, T. Hattori, T. Nakanishi, S. Ohara, S. Takami, T. Naka, H. Abe, I. Kumagai and T. Adschiri, J. Phys. Chem. B, 2010, 114, 480-486.

18 S. V. Patwardhan, G. Patwardhan and C. C. Perry, J. Mater. Chem., 2007, 17, 2875-2884.

19 M. Okochi, T. Sugita, S. Furusawa, M. Umetsu, T. Adschiri and H. Honda, Biotechnol. Bioeng., 2010, 106, 845-851.

20 I. Bertini, Biological inorganic chemistry: structure and reactivity, University Science Books, Sausalito, California, 2007.

21 P. Gerstel, P. Lipowsky, O. Durupthy, R. C. Hoffmann, P. Bellina, J. Bill and F. Aldinger, J. Ceram. Soc. Jpn., 2006, 114, 911-917. 
22 J. Baier, T. Naumburg, N. Blumenstein, L. Jeurgens, U. Welzel and J. Pleiss, Biointerface Res. Appl. Chem., 2012, 2, 380-391.

23 H. H. Wang, C. S. Xie, D. W. Zeng and Z. H. Yang, J. Colloid Interface Sci., 2006, 297, 570-577.

24 Y. Wang, Y. Li, Z. Zhou, X. Zu and Y. Deng, J. Nanopart. Res., 2011, 13, 5193-5202.

25 L. Poul, N. Jouini and F. Fievet, Chem. Mater., 2000, 12, 3123-3132.

26 M. S. Tokumoto, S. H. Pulcinelli, C. V. Santilli and V. Briois, J. Phys. Chem. B, 2003, 107, 568-574.

27 E. Jang, J. Won, Y. Kim, Z. Cheng and J. Choy, J. Solid State Chem., 2010, 183, 1835-1840.

28 G. Patrinoiu, J. M. Calderon-Moreno, D. C. Culita, R. Birjega, R. Ene and O. Carp, Solid State Sci., 2013, 23, 58-64.

29 E. Hosono, S. Fujihara, T. Kimura and H. Imai, J. Colloid Interface Sci., 2004, 272, 391-398.

30 J. J. Yoreo and P. G. Vekilov, Rev. Mineral. Geochem., 2003, 54, 57-93.

31 M. Liang, M. J. Limo, A. Sola-Rabada, M. J. Roe and C. C. Perry, Chem. Mater., 2014, 26, 4119-4129.

32 Y. Masuda, N. Kinoshita and K. Koumoto, Electrochim. Acta, 2007, 53, 171-174.

33 Q. Cui, K. Yu, N. Zhang and Z. Zhu, Appl. Surf. Sci., 2008, 254, 3517-3521.

34 Z. L. Wang, J. Phys.: Condens. Matter, 2004, 16, R829, DOI: 10.1088/0953-8984/16/25/R01.

35 H. Morioka, H. Tagaya, J. Kadokawa and K. Chiba, J. Mater. Sci. Lett., 1999, 18, 995-998.

36 A. Kasai and S. Fujihara, Inorg. Chem., 2006, 45, 415-418.

37 Z. Xia, Y. Wang, Y. Fang, Y. Wan, W. Xia and J. Sha, J. Phys. Chem. C, 2011, 115, 14576-14582.

38 H. Amekura, Y. Sakuma, M. Yoshitake, Y. Takeda, N. Kishimoto and Ch. Buchal, Nucl. Instrum. Methods Phys. Res., Sect. B, 2007, 257, 64-67.

39 S. Inoue and S. Fujihara, Inorg. Chem., 2011, 50, 3605-3612.
40 K. Nakamoto, Infrared and Raman Spectra of Inorganic and Coordination Compounds, John Wiley \& Sons Inc, New York, 1986.

41 T. Schmidt, G. Muller, L. Spanhel, K. Kerkel and A. Forchel, Chem. Mater., 1998, 10, 65-71.

42 M. Rombach, M. Gelinsky and H. Vahrenkamp, Inorg. Chim. Acta, 2002, 334, 25-33.

43 R. Vogler, M. Gelinsky, L. F. Guo and H. Vahrenkamp, Inorg. Chim. Acta, 2002, 339, 1-8.

44 ChemAxon, Marvin 5.0.0 was used for drawing and characterizing chemical structures and substructures, http:// www.chemaxon.com/.

45 B. Hess, C. Kutzner, D. van der Spoel and E. Lindahl, J. Chem. Theory Comput., 2008, 4, 435-447.

46 W. Humphrey, A. Dalke and K. Schulten, J. Mol. Graphics Modell., 1996, 14, 33-38.

47 D. T. Clark, J. Peeling and L. Colling, Biochim. Biophys. Acta, 1976, 453, 533-545.

48 O. Cavalleri, G. Gonella, S. Terreni, M. Vignolo, L. Floreano, A. Morgante, M. Canepa and R. Rolandi, Phys. Chem. Chem. Phys., 2004, 6, 4042-4046.

49 Y. K. Gao, F. Traeger, O. Shekhah, H. Idriss and C. Woell, J. Colloid Interface Sci., 2009, 338, 16-21.

50 G. Dodero, L. De Michieli, O. Cavalleri, R. Rolandi, L. Oliveri, A. Dacca and R. Parodi, Colloids Surf., A, 2000, 175, 121-128.

51 D. G. Castner, K. Hinds and D. W. Grainger, Langmuir, 1996, 12, 5083-5086.

52 M. Volmer, M. Stratmann and H. Viefhaus, Surf. Interface Anal., 1990, 16, 278-282.

53 M. A. Verges, A. Mifsud and C. J. Serna, Surf. Interface Anal., 1990, 86, 959-963.

54 J. Zhang, H. Liu, Z. Wang and N. Ming, J. Cryst. Growth, 2008, 310, 2848-2853.

55 A. Brif, G. Ankonina, C. Drathen and B. Pokroy, Adv. Mater., 2014, 26, 477-481.

56 W. Chan and P. White, Fmoc Solid Phase Peptide Synthesis: A Practical Approach, Oxford University Press, New York, 2000. 